\title{
Reduction of Maximum and Residual Drifts on Posttensioned Steel Frames with Semirigid Connections
}

\author{
Arturo López-Barraza, ${ }^{1}$ Edén Bojórquez, ${ }^{2}$ Sonia E. Ruiz, ${ }^{1}$ and Alfredo Reyes-Salazar ${ }^{2}$ \\ ${ }^{1}$ Coordinación de Mecánica Aplicada, Instituto de Ingeniería, Universidad Nacional Autónoma de México, \\ Ciudad Universitaria, Coyoacán, 04510 México City, Mexico \\ ${ }^{2}$ Facultad de Ingeniería, Universidad Autónoma de Sinaloa, Calzada de las Américas y Boulevard Universitarios S/N, \\ Ciudad Universitaria, 80040 Culiacán, Sinaloa, Mexico
}

Correspondence should be addressed to Edén Bojórquez; eden@uas.edu.mx

Received 24 October 2012; Revised 8 January 2013; Accepted 8 January 2013

Academic Editor: John W. Gillespie

Copyright (C) 2013 Arturo López-Barraza et al. This is an open access article distributed under the Creative Commons Attribution License, which permits unrestricted use, distribution, and reproduction in any medium, provided the original work is properly cited.

\begin{abstract}
The aim of this paper is to study the seismic performance of self-centering moment-resisting steel frames with posttensioned connections taking into account nonlinear material behavior, for better understanding of the advantages of this type of structural system. Further, the seismic performance of traditional structures with rigid connections is compared with the corresponding equivalent posttensioned structures with semirigid connections. Nonlinear time history analyses are developed for both types of structural systems to obtain the maximum and the residual interstory drifts. Thirty long-duration narrow-banded earthquake ground motions recorded on soft soil sites of Mexico City are used for the analyses. It is concluded that the structural response of steel buildings with posttensioned connections subjected to intense earthquake ground motions is reduced compared with the seismic response of traditional buildings with welded connections. Moreover, residual interstory drift demands are considerably reduced for the system with posttensioned connections, which is important to avoid the demolition of the buildings after an earthquake.
\end{abstract}

\section{Introduction}

Moment-resisting steel frames (MRSFs) with posttensioned connections (PTCs) represent a viable alternative to traditional steel frames with welded beam-column connections (FWCs). The posttensioned frames with semirigid connections (FPTCs) have been recently proposed as an alternative for controlling the structural damage and to improve the behavior of steel structures in seismic areas [1-12]. The system is designed to prevent brittle fractures in the nodes' areas of steel frames, which may cause reduction in the ductility capacity of the frame (as occurred in many cases during the 1994 Northridge earthquake). The beams are posttensioned to the columns by high strength posttensioning strands oriented in parallel to the axis of the beam, which provides capacity of self-centering of the frame, reducing the maximum and particularly the residual drifts and, at the same time, providing energy dissipation capacity through special devices placed in the connections.

While the control of maximum interstory drift is very important because it is one of the main parameters recommended by seismic design codes to assess the performance of structures, the energy dissipation capacity is crucial for structures subjected to long-duration narrow-band ground motions [13-16]. Finally, residual drift demands are an important parameter to decide if a structure is repaired or demolished after the occurrence of an intense earthquake. This problem has been addressed by several authors. For example, MacRae and Kawashima [17] studied the residual displacements of inelastic single-degree-of-freedom (SDOF) systems and illustrated their significant dependence on the postyielding stiffness ratio. Christopoulos et al. [18] studied residual displacements of five SDOF systems using different hysteretic rules and suggested that this type of displacements 


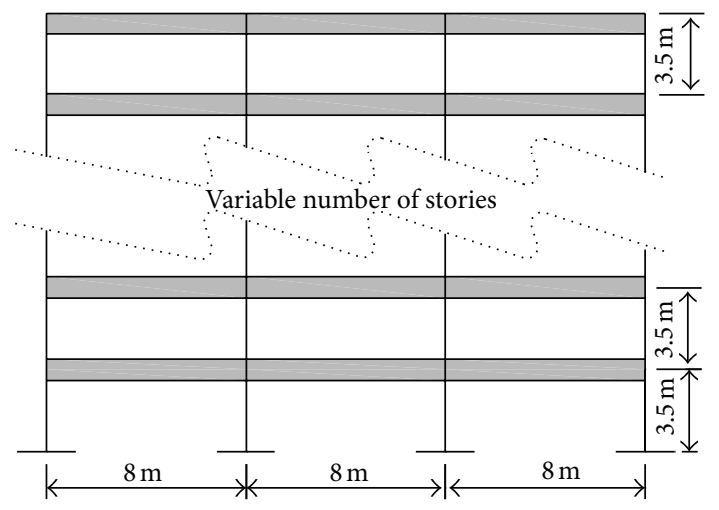

FIGURE 1: Geometrical characteristics of the frames.

decrease when the postyielding stiffness ratio increases. RuizGarcia and Miranda [19] showed that residual displacements are more sensitive to changes in local site conditions, earthquake magnitude, distance to the source range, and hysteretic behavior than peak displacements. Pampanin et al. [20] studied the seismic response of multidegree-of-freedom (MDOF) systems and highlighted a significant sensitivity of residual drifts to the hysteretic rule, postyield stiffness ratio, and global plastic mechanism. McCormick et al. [21] addressed the issue of discomfort of the occupants of the buildings due to residual deformations; they reported that significant discomfort is felt by occupants of building with residual interstory drift around $0.8 \%$. Based on past experiences of buildings that have undergone differential settlement, they propose a residual drift limit of $0.5 \%$ to be considered in performance-based seismic design. They also reported that repairing damaged structures with residual story drifts greater than $0.5 \%$ after the 1995 Hyogoken-Nanbu earthquake was not financially viable. Moreover, in a recent study, Bojórquez and Ruiz-García [22] concluded that the residual interstory drift demands in traditional steel buildings are larger than $0.5 \%$ when subjected to long-duration earthquake ground motions. Their study was developed considering buildings designed for controlling the maximum interstory drift with new seismic design guidelines.

Motivated by the limitations of the traditional momentresisting steel frames to achieve satisfactory seismic performance, and because most of the studies to estimate the seismic performance of structures with posttensioned connections are developed using broad-band records [10, 12], long-duration narrow-band earthquake ground motions recorded on very soft soil as those taken from Mexico City are not commonly used. The objective of the present study is to compare the seismic performance of traditional steel frames with posttensioned structures with semirigid connections. For this aim, six moment-resisting steel frame models with different numbers of stories have been subjected to a set of thirty narrow-band earthquake ground motions recorded on soft soil of Mexico City. Three frames are representative of traditional MRSFs with welded connections and the others, of equivalent frames with posttensioned semirigid connections. It is shown that the posttensioned structural systems can
TABLE 1: Relevant characteristics of the steel frames.

\begin{tabular}{|c|c|c|c|}
\hline Frame & F6 & F8 & F10 \\
\hline Number of stories & 6 & 8 & 10 \\
\hline \multicolumn{4}{|c|}{ Internal columns } \\
\hline Story 1 & $\mathrm{~W} 30 \times 173$ & $\mathrm{~W} 36 \times 210$ & $\mathrm{~W} 36 \times 280$ \\
\hline Story 2 & $\mathrm{~W} 30 \times 173$ & $\mathrm{~W} 36 \times 210$ & $\mathrm{~W} 36 \times 280$ \\
\hline Story 3 & $\mathrm{~W} 30 \times 148$ & W36 × 194 & $\mathrm{~W} 36 \times 245$ \\
\hline Story 4 & $\mathrm{~W} 30 \times 148$ & W36 × 194 & $\mathrm{~W} 36 \times 245$ \\
\hline Story 5 & $\mathrm{~W} 30 \times 124$ & $\mathrm{~W} 36 \times 170$ & $\mathrm{~W} 36 \times 210$ \\
\hline Story 6 & $\mathrm{~W} 30 \times 124$ & W36 $\times 170$ & $\mathrm{~W} 36 \times 210$ \\
\hline Story 7 & & $\mathrm{~W} 36 \times 160$ & W36 × 182 \\
\hline Story 8 & & $\mathrm{~W} 36 \times 160$ & $\mathrm{~W} 36 \times 182$ \\
\hline Story 9 & & & $\mathrm{~W} 36 \times 150$ \\
\hline Story 10 & & & $\mathrm{~W} 36 \times 150$ \\
\hline \multicolumn{4}{|c|}{ External columns } \\
\hline Story 1 & $\mathrm{~W} 27 \times 146$ & $\mathrm{~W} 36 \times 194$ & $\mathrm{~W} 36 \times 280$ \\
\hline Story 2 & $\mathrm{~W} 27 \times 146$ & W36 × 194 & $\mathrm{~W} 36 \times 280$ \\
\hline Story 3 & $\mathrm{~W} 27 \times 129$ & W36 $\times 182$ & $\mathrm{~W} 36 \times 245$ \\
\hline Story 4 & W27 × 129 & W36 × 182 & $\mathrm{~W} 36 \times 245$ \\
\hline Story 5 & $\mathrm{~W} 27 \times 114$ & $\mathrm{~W} 36 \times 160$ & $\mathrm{~W} 36 \times 210$ \\
\hline Story 6 & $\mathrm{~W} 27 \times 114$ & $\mathrm{~W} 36 \times 160$ & $\mathrm{~W} 36 \times 210$ \\
\hline Story 7 & & W36 × 135 & $\mathrm{~W} 36 \times 182$ \\
\hline Story 8 & & W36 × 135 & $\mathrm{~W} 36 \times 182$ \\
\hline Story 9 & & & $\mathrm{~W} 36 \times 150$ \\
\hline Story 10 & & & W36 $\times 150$ \\
\hline \multicolumn{4}{|c|}{ Beams } \\
\hline Story 1 & $\mathrm{~W} 18 \times 71$ & $\mathrm{~W} 21 \times 83$ & $\mathrm{~W} 21 \times 68$ \\
\hline Story 2 & $\mathrm{~W} 18 \times 76$ & $\mathrm{~W} 21 \times 93$ & $\mathrm{~W} 21 \times 93$ \\
\hline Story 3 & $\mathrm{~W} 18 \times 76$ & $\mathrm{~W} 21 \times 93$ & $\mathrm{~W} 21 \times 101$ \\
\hline Story 4 & $\mathrm{~W} 16 \times 67$ & $\mathrm{~W} 21 \times 83$ & $\mathrm{~W} 21 \times 101$ \\
\hline Story 5 & $\mathrm{~W} 16 \times 50$ & $\mathrm{~W} 18 \times 71$ & $\mathrm{~W} 21 \times 101$ \\
\hline Story 6 & $\mathrm{~W} 16 \times 45$ & $\mathrm{~W} 18 \times 65$ & $\mathrm{~W} 21 \times 93$ \\
\hline Story 7 & & $\mathrm{~W} 18 \times 55$ & $\mathrm{~W} 21 \times 73$ \\
\hline Story 8 & & $\mathrm{~W} 18 \times 46$ & W $21 \times 68$ \\
\hline Story 9 & & & $\mathrm{~W} 21 \times 57$ \\
\hline Story 10 & & & $\mathrm{~W} 21 \times 50$ \\
\hline
\end{tabular}

reduce considerably the maximum and residual interstory drift demands when subjected to long-duration earthquake ground motions.

\section{Structural Models}

2.1. Steel Frame Models. Six structural steel frames are analyzed in the present study. Three corresponds to FWC, and the rest are representatives of FPTC. The first group of structures was designed according to the Mexico City Building Code [23]. The buildings are assumed to be for office occupancy. They have 6, 8, and 10 stories and 3 bays; hereafter identified as F6WC, F8WC, and F10WC, respectively. The dimensions of the frames are shown in Figure 1. The beams and columns are A36 steel W sections. A bilinear hysteretic model for accounting the nonlinear material behavior with $3 \%$ of postyielding stiffness was considered for the analyses, 

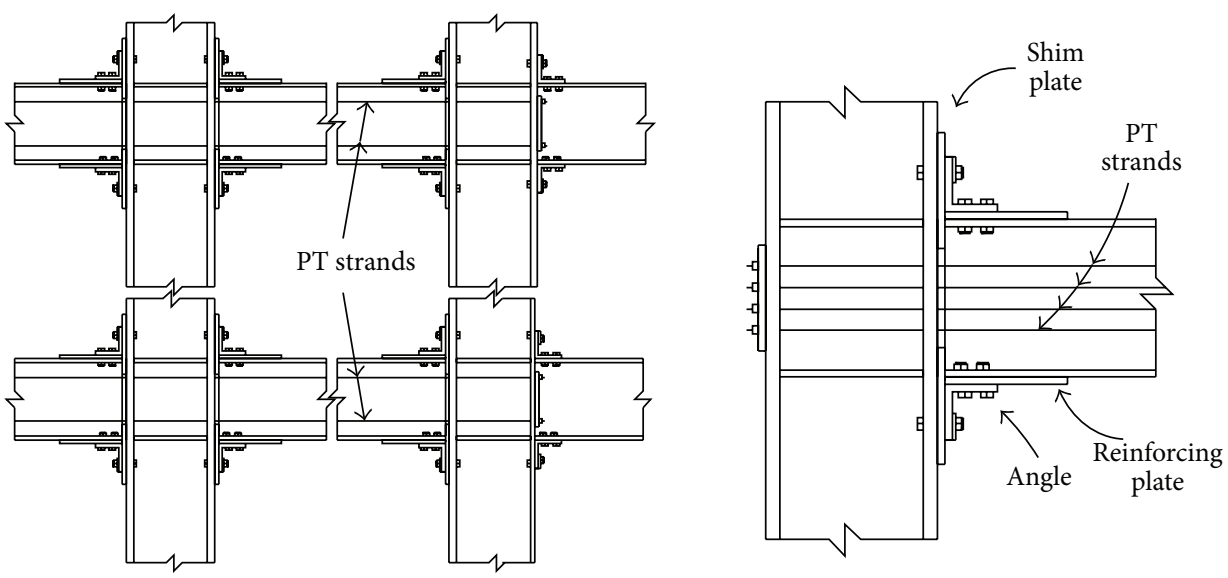

FIgURE 2: Angles and posttensioned strands in FPTC.

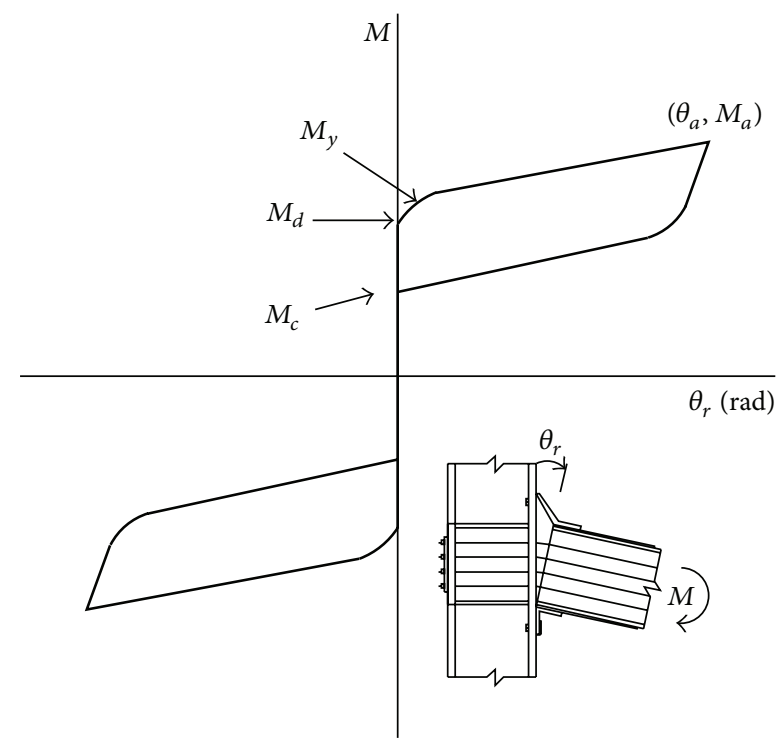

FIGURE 3: Moment-relative rotation hysteretic curve of the posttensioned connection.

and the damping used was $3 \%$ of critical. The fundamental periods of vibration $\left(T_{1}\right)$ are $1.07,1.20$, and $1.37 \mathrm{~s}$, respectively. On the other hand, the FPTCs were designed in accordance with the recommendations proposed by Garlock et al. [6], which basically start with the design of the steel frames as usually is done (considering rigid connections), then the semirigid posttensioned connections are designed to satisfy the requirements of the serviceability and resistance conditions. The beam-column connections consist of two angles bolted to the flanges of the beam and to the column flange (top and seat). For the design of posttensioned connections, steel grade 50 was used for the angles. The length of the angles was taken equal to the width of the flange of the beams $\left(b_{f}\right)$. Different angle sizes were tested. In the end, $152 \times 152 \times 13 \mathrm{~mm}$ angles were used in all the cases. Posttensioned cables consist of seven wires with an area of $150 \mathrm{~mm}^{2}$ and withstanding a load of $279 \mathrm{kN}$; they are parallel to the axis of the beam

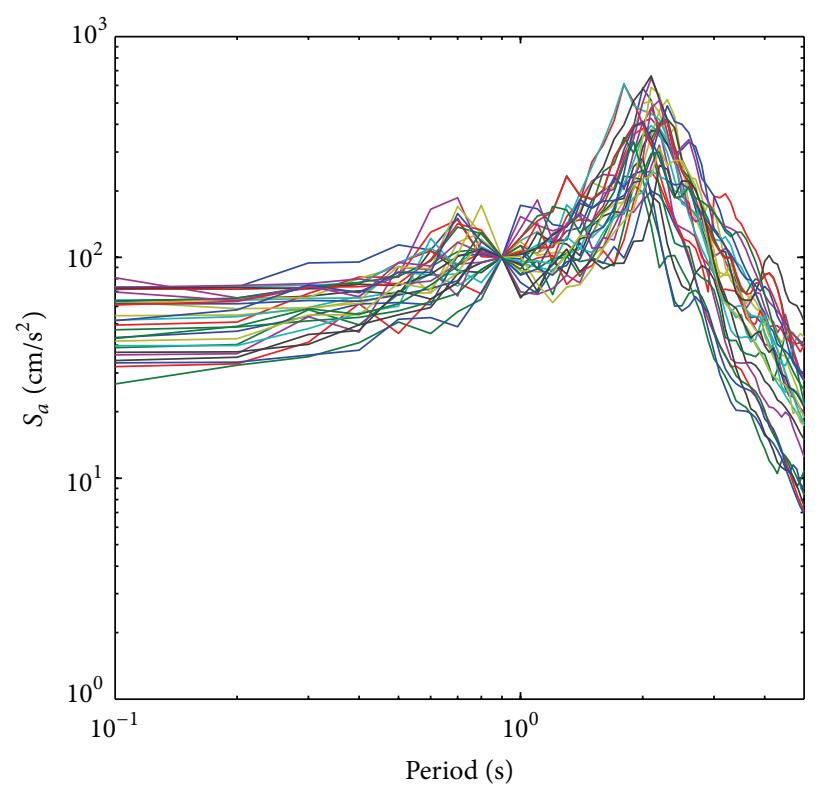

FIGURE 4: Elastic response spectra for the records scaled at the same spectral acceleration $S_{a}\left(T_{1}\right)=100 \mathrm{~cm} / \mathrm{s}^{2}$ for period equal to $0.9 \mathrm{~s}$ and $3 \%$ of critical damping.

passing through the interior columns and fixed to the outer face of the columns at the ends of the frame. An initial tension of the cables less than 0.33 of their maximum capacity was used according to the suggestions given by Garlock et al. [6]. The three FPTC models are identified here as F6PTC, F8PTC, and F10PTC, for the frames with 6, 8, and 10 stories, respectively. The FPTC models have fundamental periods of vibration of $1.03,1.25$, and $1.37 \mathrm{~s}$, respectively. The columns of the ground floor are fixed at the base without posttensioned. The beam and column members used for all the frames are illustrated in Table 1 . Note that the mechanical characteristics and dimensions of beams and columns are the same for both FWC and FPTC. Figure 2 shows a typical assembly of a posttensioned steel frame, where the posttensioned strands 


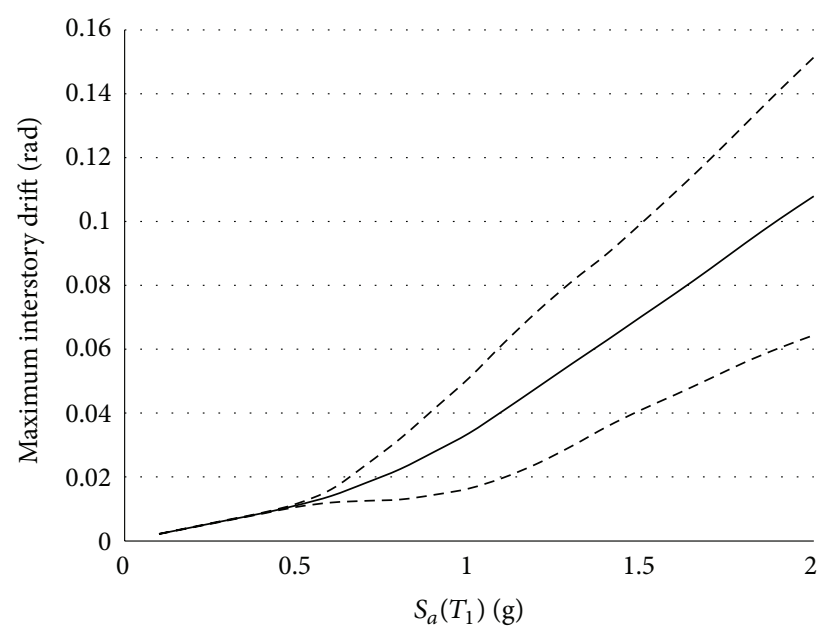

(a) F6WC

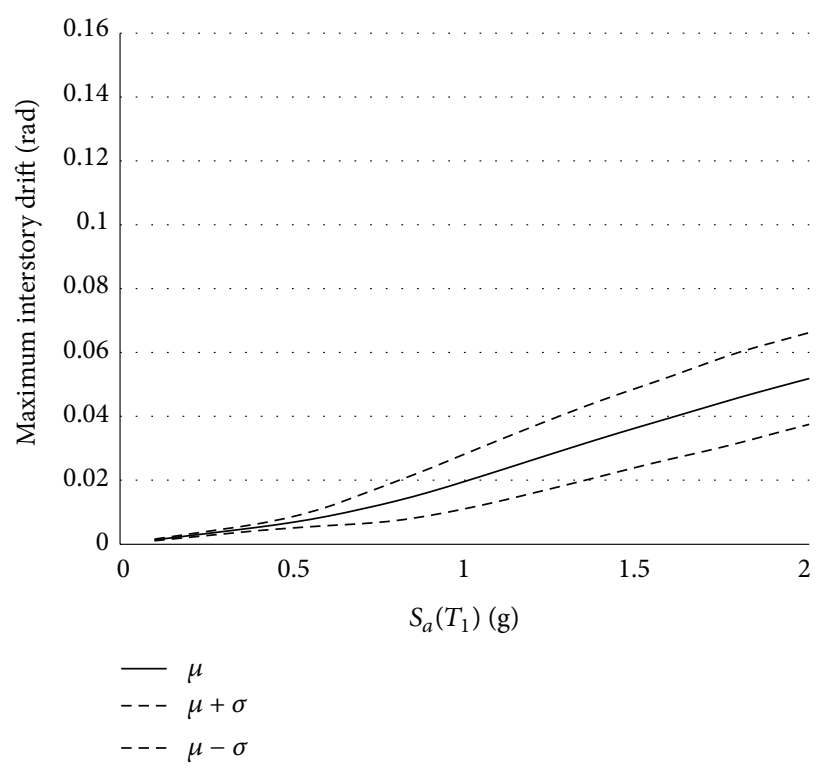

(c) F6PTC

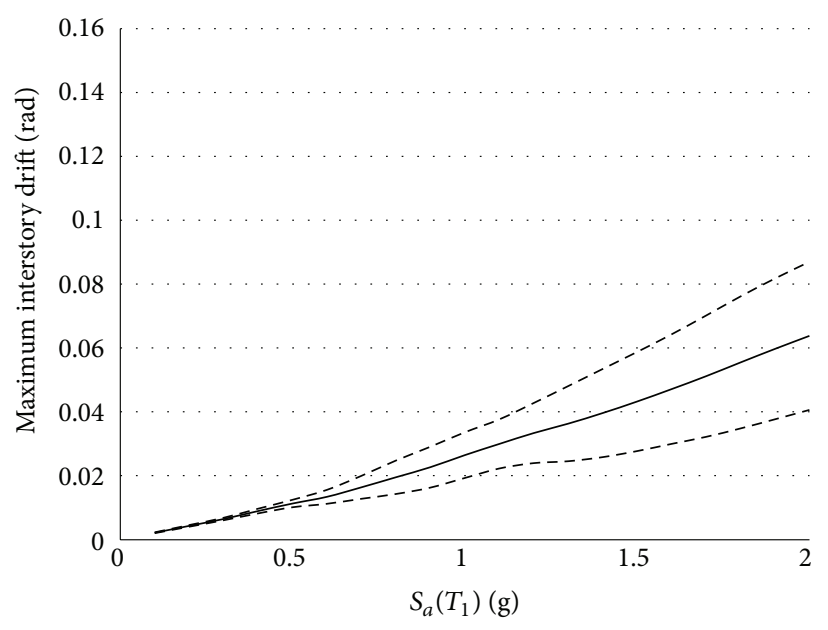

(b) F10WC

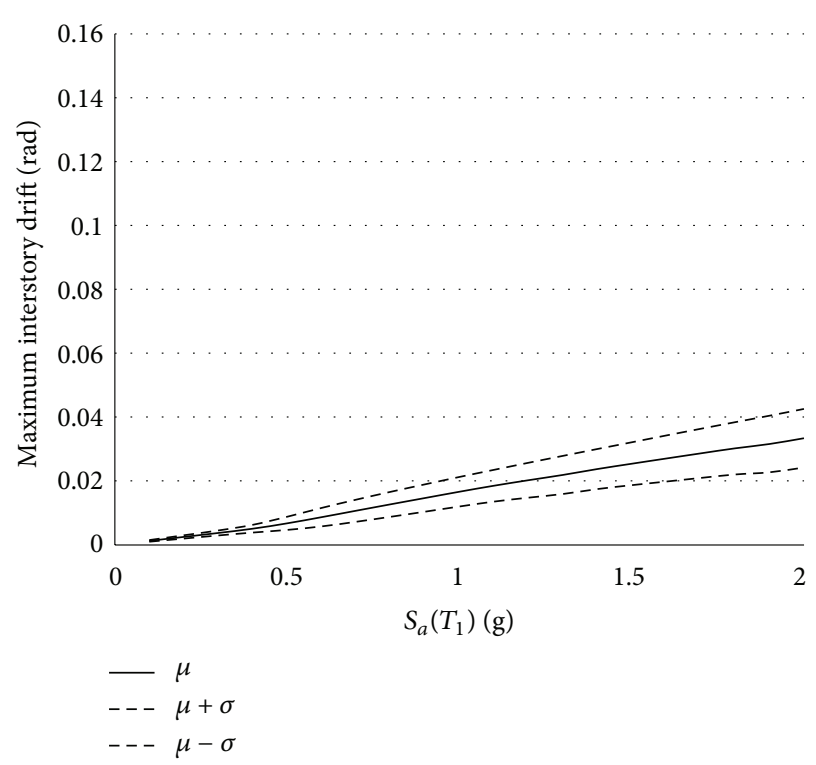

(d) F10PTC

FIGURE 5: Median values of maximum interstory drifts \pm one standard deviation for models: (a) F6WC, (b) F10WC, (c) F6PTC, and (d) F10PTC.

can be identified and the energy-dissipating elements (bolted angles) can be observed.

2.2. Connection Model: Nonlinear Behavior. The nonlinear behavior or hysteretic rules that represent the cyclic behavior of the semirigid connections of the posttensioned frames are characterized by moment-rotation curves $(M-\theta r)$, which usually present shapes similar to a flag. This representation characterizes the nonlinearity, self-centering capability, and energy dissipation capacity of the connection. Experimental tests with isolated angles, subjected to cyclic and monotonic loads conducted by Shen and Astaneh-Asl [24], showed a stable cyclic response and good capability of hysteretic energy dissipation. In general, ultimate strength exceeds 3 times the yield strength and ductility reached values between 8 and 10 . The strength and stiffness in bending of the posttensioned connections is provided by the contribution of the angles of the PTC and by posttensioned strands. Wires and angles work as springs in parallel. Posttensioned strands exhibit linear behavior, while connecting angles behave nonlinearly. Figure 3 shows a typical example of a hysteretic curve corresponding to a posttensioned connection. This behavior was modeled by using (1) and (2) which represent the loading and unloading curves, respectively, which in turn were obtained from the superposition of the exponential equation proposed by Richard and Abbott [25] for semirigid connections, considering the linear contribution of the strands, decompression moments $\left(M_{d}\right)$, and the closing moment $\left(M_{c}\right)$ of the connection. The first function, given by (1), 


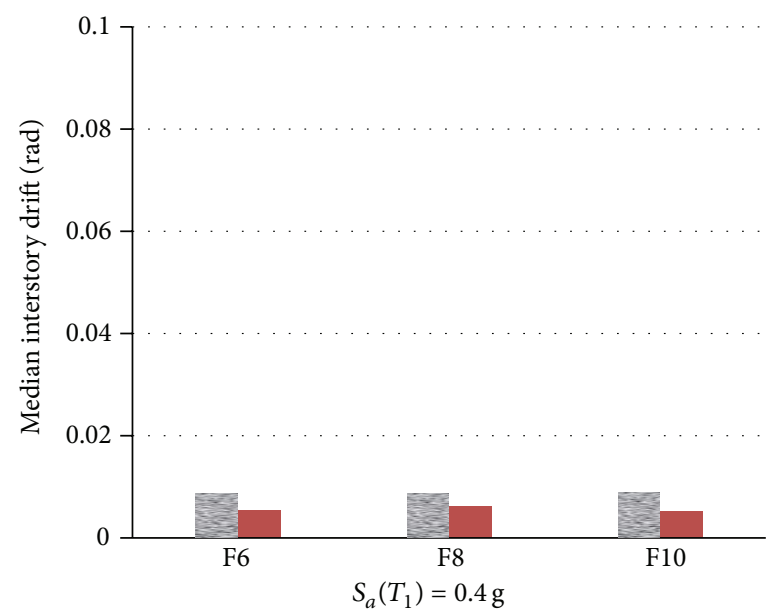

(a)

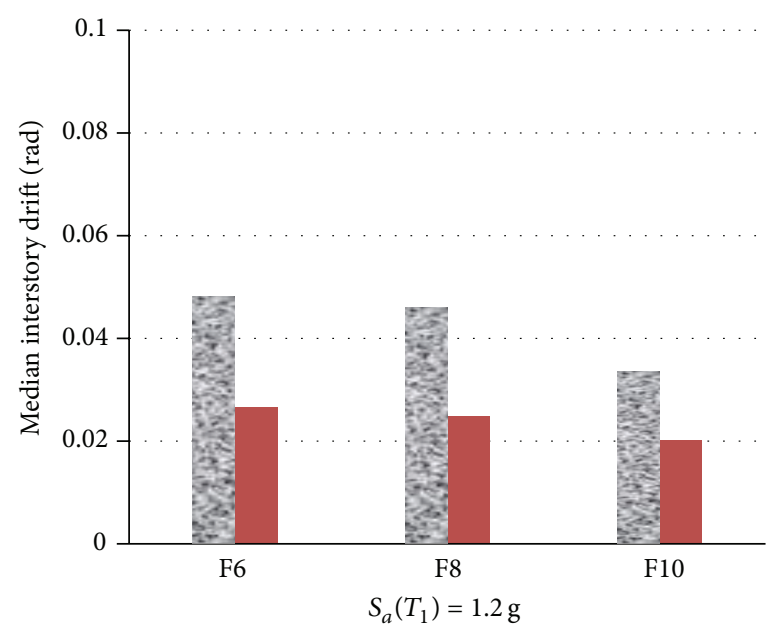

(c)

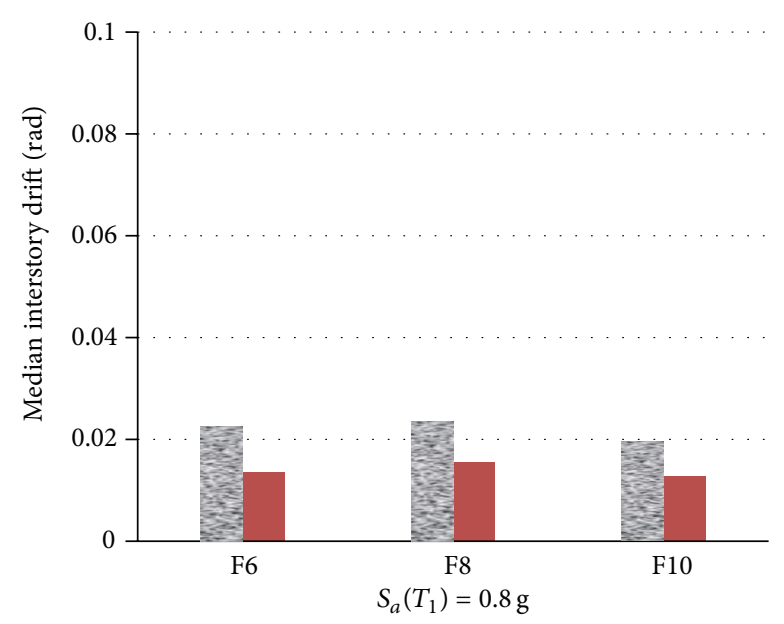

(b)

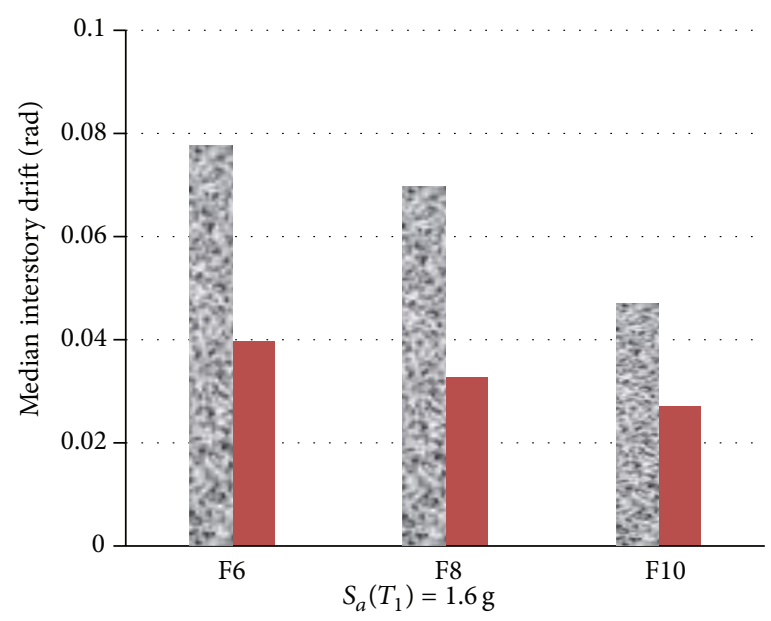

(d)

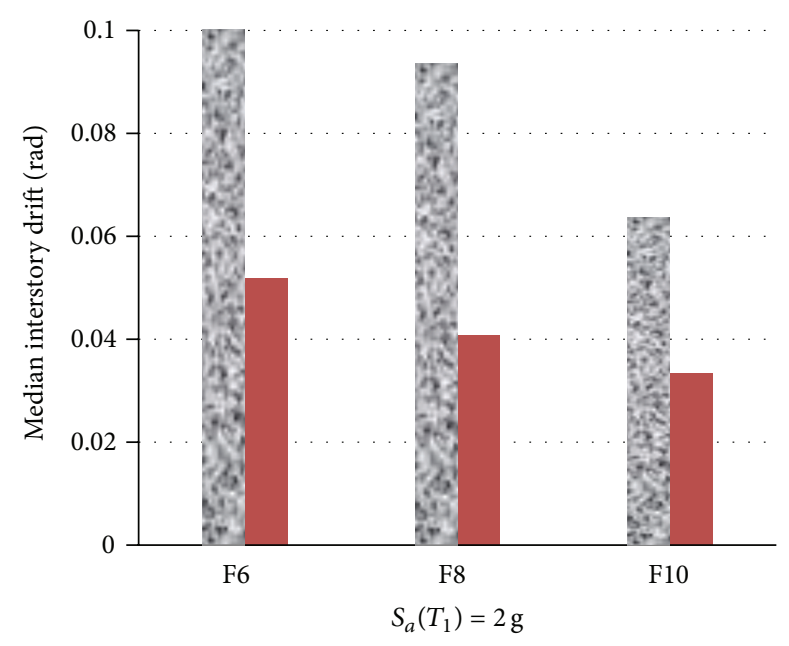

FWC

FPTC

(e)

FIGURE 6: Median of maximum interstory drift of the frames FWC and FPTC. 


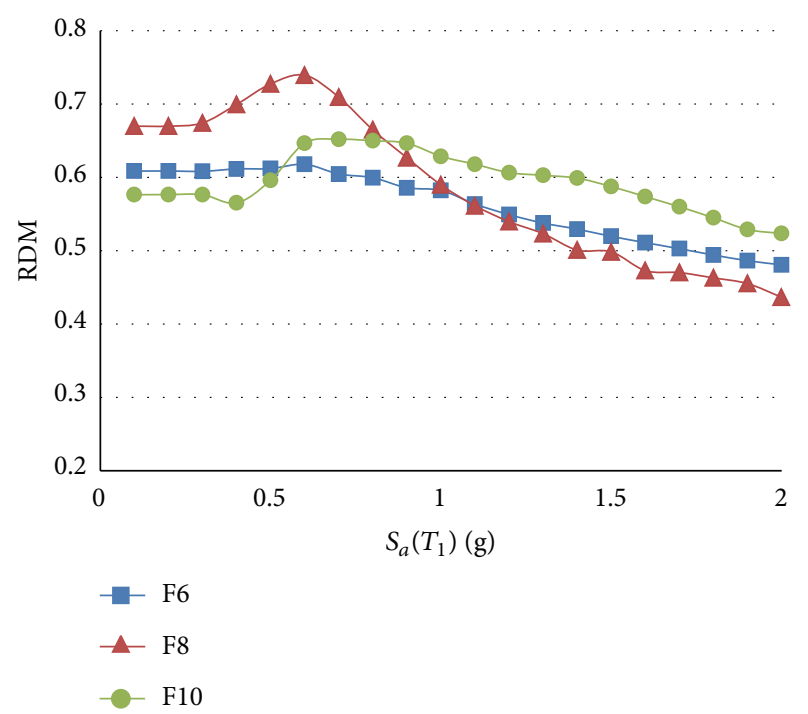

FIGURE 7: Ratio of median values of IDR $_{\max }$ for FPTC divided by $\mathrm{IDR}_{\max }$ for FWC.

corresponds to the initial loading cycle; two types of variables are observed: (1) variables depending only on geometric and physical properties of angles, such as initial $(k)$ and postyield $\left(k_{p}\right)$ stiffness, the reference moment $\left(M_{o}\right)$, and $N$ that defines the curvature in the transition between the linear and plastic behavior, and (2) variables depending on the number and type of tendons such as the rigidity of the posttensioned tendons $\left(k_{\theta S}\right)$ and the bending moment associated to the opening of the connection (named decompression moment, $M_{d}$ ) which is a function of the resulting initial tension in the tendons. The second function, given by (2), defines the unloading and reloading process in the connection; $M_{a}$ and $\theta_{a}$ are the maximum values reached in each cycle, and the parameter $\varphi$ defines the magnitude of the closing moment of the connection $\left(M_{c}\right)$, which must be greater than zero in order to insure complete closure of the connection after getting complete unloading; moreover, this parameter largely defines the $E_{H}$ dissipation capacity of the connection (enclosed area). The curves obtained with the modified model exhibit good accuracy in comparison with experiment results [5], and they were modeled in RUAUMOKO [26] as the flagshaped bi-linear hysteresis,

$$
\begin{aligned}
M= & M_{d}+\frac{\left(k-k_{p}\right) \theta_{r}}{\left[1+\left|\left(k-k_{p}\right) \theta_{r} / M_{o}\right|^{N}\right]^{1 / N}}+\left(k_{p}+k_{\theta S}\right) \theta_{r} \\
M= & M_{a}-\frac{\left(k-k_{p}\right)\left(\theta_{a}-\theta_{r}\right)}{\left[1+\left|\left(k-k_{p}\right)\left(\theta_{a}-\theta_{r}\right) / \varphi M_{o}\right|^{N}\right]^{1 / N}} \\
& -\left(k_{p}+k_{\theta S}\right)\left(\theta_{a}-\theta_{r}\right)
\end{aligned}
$$

\section{Earthquake Ground Motion Records}

A set of 30 long-duration narrow-band ground motions recorded at Lake Zone sites of Mexico City was considered. Particularly, all motions were recorded at sites having soil periods of $2 \mathrm{~s}$, during seismic events with magnitudes near of seven or larger and having epicenters located at distances of $300 \mathrm{~km}$ or more from Mexico City. Some important characteristics of the records are summarized in Table 2. While PGA and PGV denote the peak ground acceleration and velocity, respectively, the duration $\left(t_{D}\right)$ was estimated according to Trifunac and Brady [27]. It should be mentioned that sites having soil periods of $2 \mathrm{~s}$ are fairly common within the Lake Zone and that the higher levels of shaking (in terms of PGA) have been consistently observed at these sites. Further, the long-duration narrow-band ground motion records demand large amounts of energy to structures compared with those subjected to broad-band ground motion [14]. The ground motions were recorded in sites where most of the damage during the Mexico earthquake of September 19, 1985, occurred.

Figure 4 shows the elastic response spectra for the records under consideration (where $S_{a}$ denotes pseudoacceleration) corresponding to $3 \%$ of critical damping. The narrow-banded records exhibit similar values of parameter $N_{p}$, which is an indicator of the characteristics of their spectral shape [2830]; further information of this parameter can be found in [29]. As a result, there is a strong similarity between their spectral shapes when they are scaled to the same spectral acceleration at first mode of vibration. Figure 4 shows seismic response spectra for all records scaled for an elastic spectral acceleration of $100 \mathrm{~cm} / \mathrm{s}^{2}$ for a period of $0.9 \mathrm{~s}$. The similitude exhibited by all spectra indicates that the spectral acceleration is a good indicator of the damage potential of the ground motions and emphasizes the good correspondence that exists between parameter $N_{p}$ and the spectral shape of the motions. Note that the spectral acceleration of $100 \mathrm{~cm} / \mathrm{s}^{2}$ was chosen only for illustrative purposes and that the similitude exhibited by the spectra is valid for any level of scaling.

\section{Methodology}

The comparison of maximum interstory drift $\left(\mathrm{IDR}_{\max }\right)$ and peak residual interstory drift $\left(\mathrm{RIDR}_{\max }\right)$ of the traditional and posttensioned steel frames was estimated using incremental nonlinear dynamic analysis [31]. For this aim, the building frame models were subjected to the set of thirty long-duration narrow-band earthquake ground motions, which were scaled at different values of the seismic intensity in terms of spectral acceleration at first mode of vibration of the structure $S_{a}\left(T_{1}\right)$. The selected seismic intensity values were from $0.1 \mathrm{~g}$ to $2.0 \mathrm{~g}$ with increments of $0.1 \mathrm{~g}$. The RUAUMOKO [26] computer program was used for the time history nonlinear dynamic analysis.

The seismic performance results considering nonlinear behavior are expressed in terms of maximum and residual interstory drifts at the end of the earthquake motions for each scaling level. 


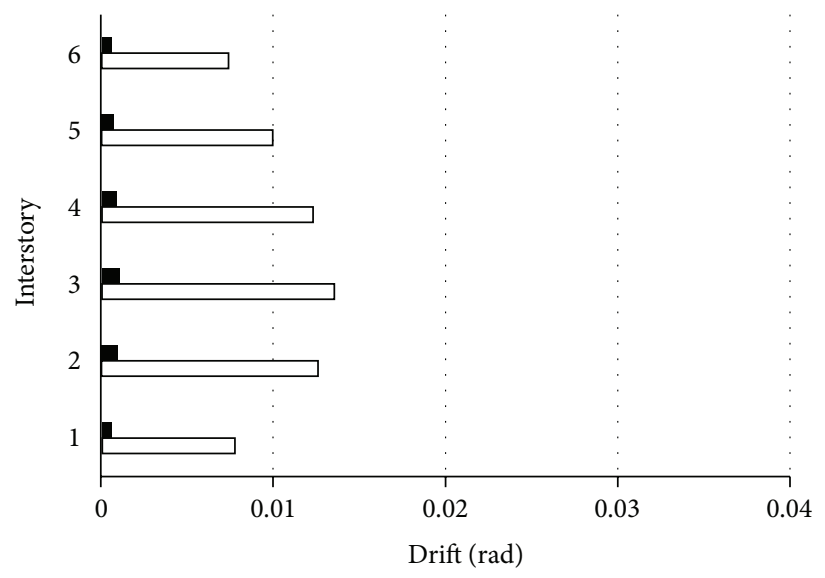

(a) $S_{a}\left(T_{1}\right)=0.8 \mathrm{~g}$

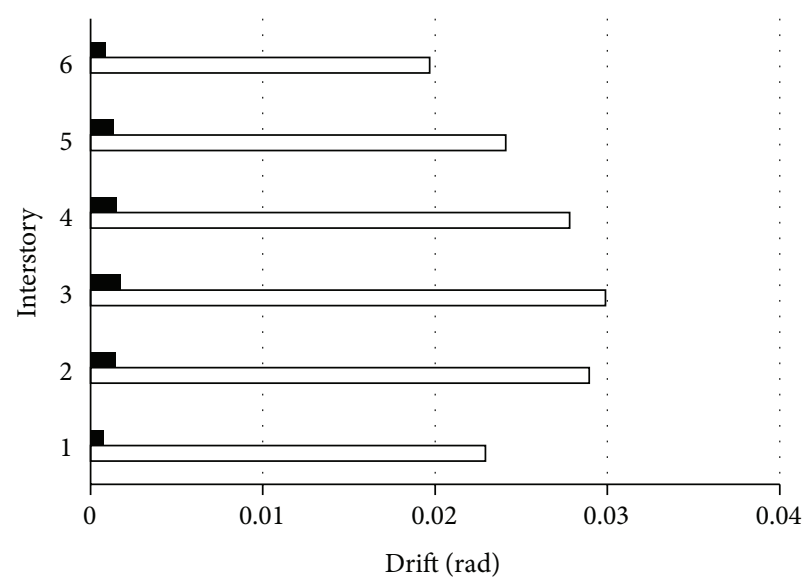

Residual

$\square$ Maximum

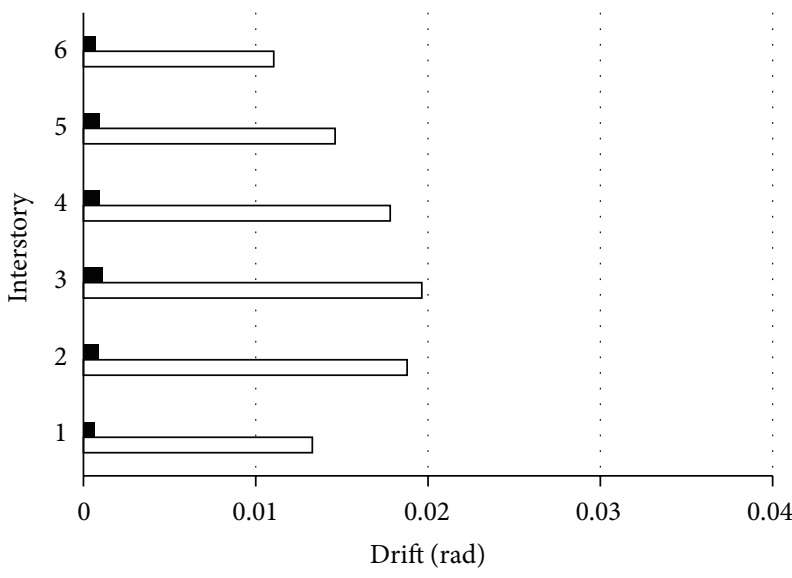

(b) $S_{a}\left(T_{1}\right)=1.0 \mathrm{~g}$

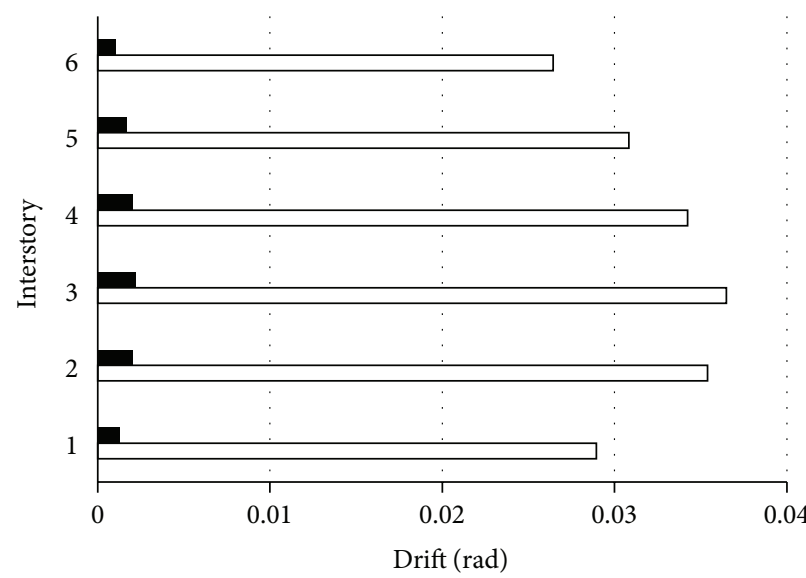

Residual

$\square$ Maximum

(c) $S_{a}\left(T_{1}\right)=1.2 \mathrm{~g}$

(d) $S_{a}\left(T_{1}\right)=1.5 \mathrm{~g}$

FIGURE 8: Median values of maximum and residual interstory drifts for F6PTC at different spectral acceleration values: (a) $0.8 \mathrm{~g}$, (b) $1.0 \mathrm{~g}$, (c) $1.2 \mathrm{~g}$, and (d) $1.5 \mathrm{~g}$.

4.1. Maximum Interstory Drift Results. The median $(\mu)$ and standard deviation $(\sigma)$ of IDR $_{\max }$ for each frame and seismic intensity level are estimated in first place. Figures 5(a), 5(b), $5(c)$, and 5(d) show the values of IDR max $_{\text {ax }}$ at different pseudospectral acceleration for frames F6WC, F10WC, F6PTC, and F10PTC, respectively. It is observed that for frames of the same height subjected to the same ground motion intensities, the median values of IDR $_{\max }$ are smaller for the FPTC than for the FWC. The difference tends to increases as the spectral acceleration also increases. Figures 5(a)-5(d) also indicate that the maximum interstory drift demands are smaller for the structures with fundamental periods equal to $1.37 \mathrm{~s}$ than for those with periods around $1.07 \mathrm{~s}$ due to the softening phenomenon that these structures suffer; it occurs because as the seismic intensity increases and the structure presents inelastic nonlinear behavior, the effective period of vibration becomes larger, which implies that it becomes closer to the peak ordinate of the spectrum. As a consequence, the structural response grows very rapidly. In other words, the structure is "softening" into the peak of the spectrum, as it is shown in Montiel and Ruiz [32]. Note that the uncertainty in the estimation of maximum interstory drift is larger for the steel frames with rigid connections compared with the FPTC (see Figure 5). Moreover, for the FPTC models, $\mathrm{IDR}_{\max }$ tend to increase almost linearly with $S_{a}\left(T_{1}\right)$. This can be explained observing that the strands remain elastic which significantly contribute to the stiffness capacity of the connection.

Figure 6 shows the maximum interstory drift for all frames and the ground motion intensities of $0.4 \mathrm{~g}, 0.8 \mathrm{~g}$, $1.2 \mathrm{~g}, 1.6 \mathrm{~g}$, and $2.0 \mathrm{~g}$. The figure indicates that the maximum interstory drift of the FPTC models are smaller than those of the corresponding FWC models; this difference increases as the intensity seismic demand increases. It suggests the advantages of using moment-resisting steel frames with posttensioned connections.

The ratio of the maximum interstory drift of FPTC divided by the same parameter for FWC model (here defined as Ratio of Maximum Drifts RMD) is illustrated in Figure 7 at different intensity levels. It is observed that RMD in all the cases is smaller than unity, indicating that the $\mathrm{IDR}_{\max }$ 


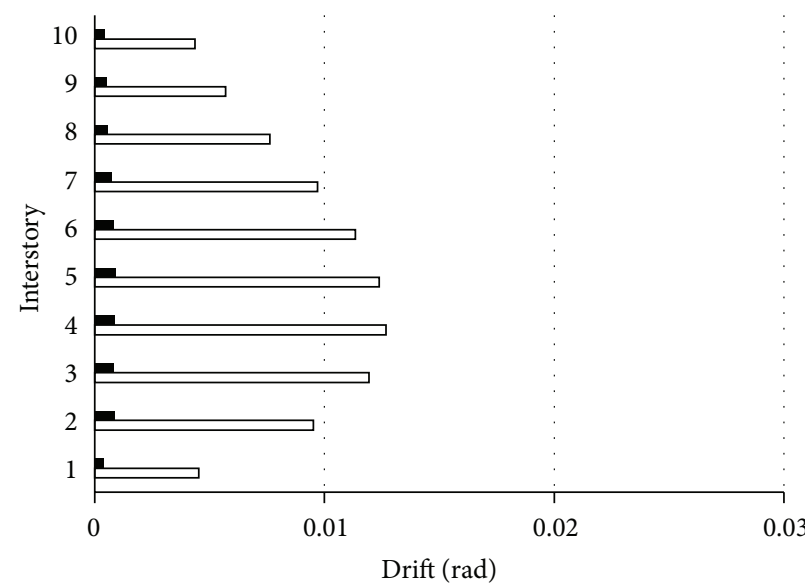

(a) $S_{a}\left(T_{1}\right)=0.8 \mathrm{~g}$

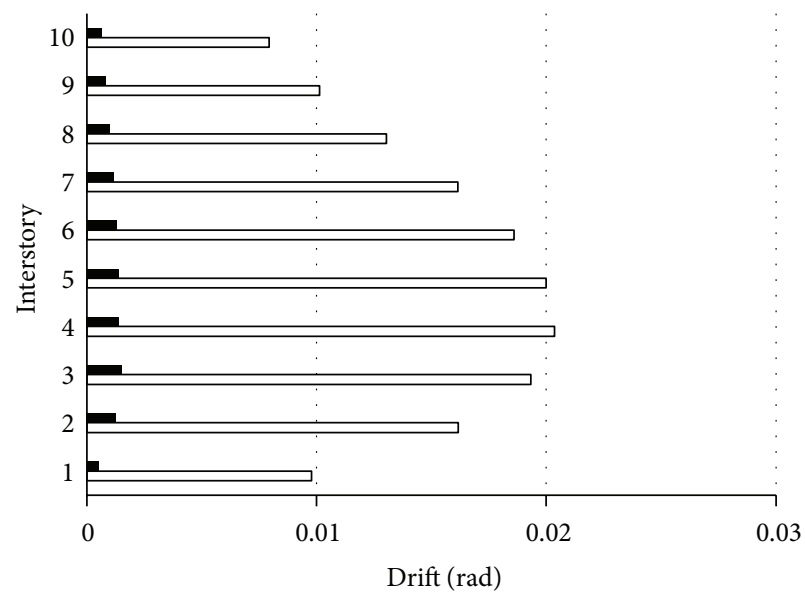

Residual

$\square$ Maximum

(c) $S_{a}\left(T_{1}\right)=1.2 \mathrm{~g}$

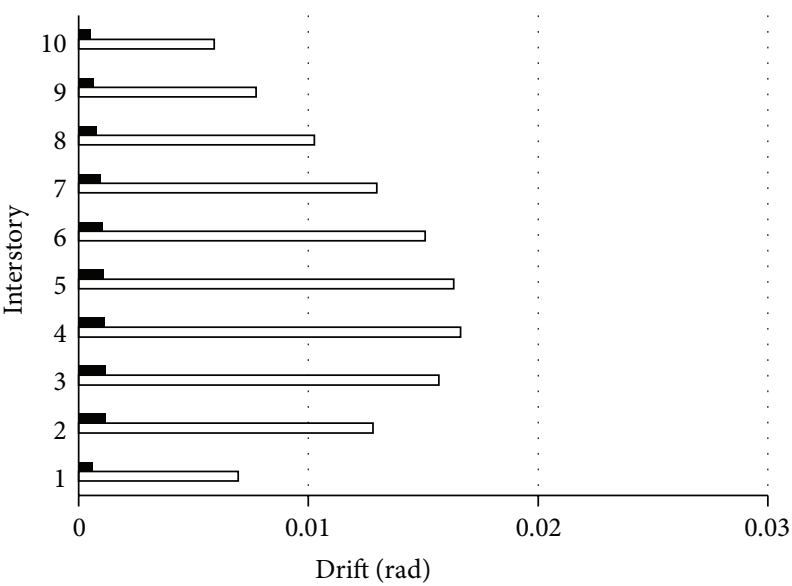

(b) $S_{a}\left(T_{1}\right)=1.0 \mathrm{~g}$

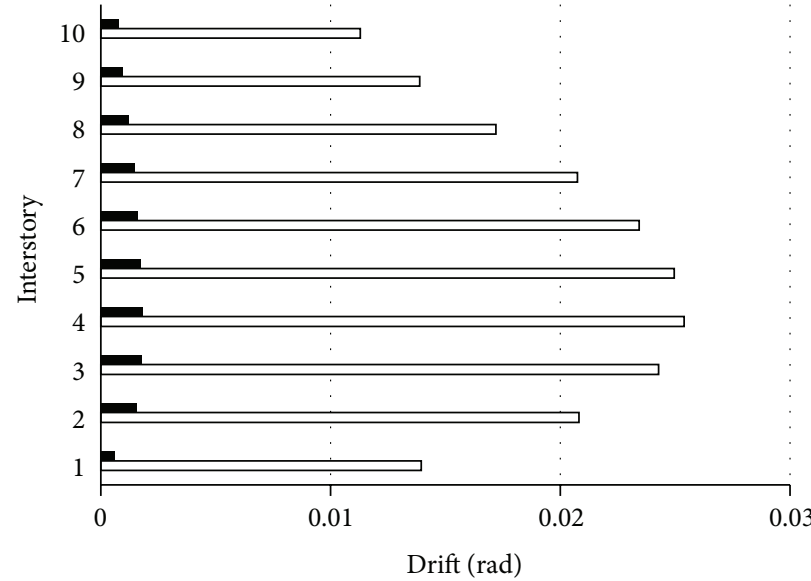

Residual

$\square$ Maximum

Figure 9: Median values of maximum and residual interstory drifts for F10PTC at different spectral acceleration values: (a) $0.8 \mathrm{~g}$, (b) $1.0 \mathrm{~g}$, (c) $1.2 \mathrm{~g}$ and (d) $1.5 \mathrm{~g}$.

values of the FPTC systems are smaller than those of the FWC system. Furthermore, for larger values of nonlinear behavior, the ratio is almost the same for all the frames analyzed with magnitude about $50 \%$, which represent an important reduction of the maximum seismic demands compared with the traditional structural steel frame models.

\subsection{Comparison of Maximum and Residual Interstory Drift} Demands. Maximum and residual interstory drift demands are compared at different intensity levels in terms of spectral acceleration in this section. The results of median values of the selected engineering demand parameters are compared in Figures 8 and 9 considering ground motion intensities of $0.8 \mathrm{~g}, 1.0 \mathrm{~g}, 1.2 \mathrm{~g}$, and $1.5 \mathrm{~g}$, for the structural models F6PTC and F10PTC. As it was expected, the magnitudes of IDR $_{\max }$ tend to increase for larger values of spectral acceleration; on the other hand, the RIDR $\mathrm{max}_{\text {ax }}$ slightly increases when $S_{a}\left(T_{1}\right)$ becomes larger. Moreover, the value of $\mathrm{RIDR}_{\max }$ is smaller than $0.5 \%$ for $S_{a}\left(T_{1}\right)$ equal to $1.5 \mathrm{~g}$, indicating that the buildings with posttensioned steel connections do not necessarily must be demolished after an earthquake. Note that the value of $0.5 \%$ of residual interstory drift was proposed by McCormick et al. [21] as the limit for feasible financially structures and to guarantee the comfort of the occupants of the buildings. Furthermore, the larger seismic demands in terms of maximum and residual deformations occur in the intermediate stories (between 0.3 and 0.6 of the height).

Figure 10 shows the median values of $\mathrm{RIDR}_{\max }$ for the frames with 6,8 , and 10 stories and spectral acceleration values from 0.1 to $2.0 \mathrm{~g}$. It can be observed that the magnitude of RIDR max $_{\text {ax }}$ increases when $S_{a}\left(T_{1}\right)$ becomes larger. For $S_{a}\left(T_{1}\right) \geq 0.5 \mathrm{~g}$, the RIDR $\max _{\max }$ of the FPTC models are smaller than those of the FWC systems. The difference increases when $S_{a}\left(T_{1}\right)$ also increases. In the case of FWC, the residual interstory drift strongly depends on the fundamental period of the frames being smaller for frames with larger fundamental period of vibration. Note that the results of the incremental dynamic analyses of the FPTC suggests that 
TABLE 2: Selected long-duration narrow-band ground motions.

\begin{tabular}{|c|c|c|c|c|c|c|}
\hline Records & Date & Magnitude & Station & PGA $\left(\mathrm{cm} / \mathrm{s}^{2}\right)$ & PGV $(\mathrm{cm} / \mathrm{s})$ & $t_{D}(\mathrm{~s})$ \\
\hline 1 & $19 / 09 / 1985$ & 8.1 & SCT & 178.0 & 59.5 & 34.8 \\
\hline 2 & 21/09/1985 & 7.6 & Tlahuac deportivo & 48.7 & 14.6 & 39.9 \\
\hline 3 & $25 / 04 / 1989$ & 6.9 & Alameda & 45.0 & 15.6 & 37.8 \\
\hline 4 & $25 / 04 / 1989$ & 6.9 & Garibaldi & 68.0 & 21.5 & 65.5 \\
\hline 5 & $25 / 04 / 1989$ & 6.9 & SCT & 44.9 & 12.8 & 65.8 \\
\hline 6 & $25 / 04 / 1989$ & 6.9 & Sector Popular & 45.1 & 15.3 & 79.4 \\
\hline 7 & $25 / 04 / 1989$ & 6.9 & Tlatelolco TL08 & 52.9 & 17.3 & 56.6 \\
\hline 8 & $25 / 04 / 1989$ & 6.9 & Tlatelolco TL55 & 49.5 & 17.3 & 50.0 \\
\hline 9 & $14 / 09 / 1995$ & 7.3 & Alameda & 39.3 & 12.2 & 53.7 \\
\hline 10 & $14 / 09 / 1995$ & 7.3 & Garibaldi & 39.1 & 10.6 & 86.8 \\
\hline 11 & $14 / 09 / 1995$ & 7.3 & Liconsa & 30.1 & 9.62 & 60.0 \\
\hline 12 & $14 / 09 / 1995$ & 7.3 & Plutarco Elías Calles & 33.5 & 9.37 & 77.8 \\
\hline 13 & $14 / 09 / 1995$ & 7.3 & Sector Popular & 34.3 & 12.5 & 101.2 \\
\hline 14 & $14 / 09 / 1995$ & 7.3 & Tlatelolco TL08 & 27.5 & 7.8 & 85.9 \\
\hline 15 & $14 / 09 / 1995$ & 7.3 & Tlatelolco TL55 & 27.2 & 7.4 & 68.3 \\
\hline 16 & 09/10/1995 & 7.5 & Cibeles & 14.4 & 4.6 & 85.5 \\
\hline 17 & 09/10/1995 & 7.5 & CU Juárez & 15.8 & 5.1 & 97.6 \\
\hline 18 & 09/10/1995 & 7.5 & Centro urbano Presidente Juárez & 15.7 & 4.8 & 82.6 \\
\hline 19 & 09/10/1995 & 7.5 & Córdoba & 24.9 & 8.6 & 105.1 \\
\hline 20 & 09/10/1995 & 7.5 & Liverpool & 17.6 & 6.3 & 104.5 \\
\hline 21 & 09/10/1995 & 7.5 & Plutarco Elías Calles & 19.2 & 7.9 & 137.5 \\
\hline 22 & 09/10/1995 & 7.5 & Sector Popular & 13.7 & 5.3 & 98.4 \\
\hline 23 & 09/10/1995 & 7.5 & Valle Gómez & 17.9 & 7.18 & 62.3 \\
\hline 24 & $11 / 01 / 1997$ & 6.9 & CU Juárez & 16.2 & 5.9 & 61.1 \\
\hline 25 & 11/01/1997 & 6.9 & Centro urbano Presidente Juárez & 16.3 & 5.5 & 85.7 \\
\hline 26 & $11 / 01 / 1997$ & 6.9 & García Campillo & 18.7 & 6.9 & 57.0 \\
\hline 27 & $11 / 01 / 1997$ & 6.9 & Plutarco Elías Calles & 22.2 & 8.6 & 76.7 \\
\hline 28 & 11/01/1997 & 6.9 & Est. no. 10 Roma A & 21.0 & 7.76 & 74.1 \\
\hline 29 & $11 / 01 / 1997$ & 6.9 & Est. no. 11 Roma B & 20.4 & 7.1 & 81.6 \\
\hline 30 & 11/01/1997 & 6.9 & Tlatelolco TL08 & 16.0 & 7.2 & 57.5 \\
\hline
\end{tabular}

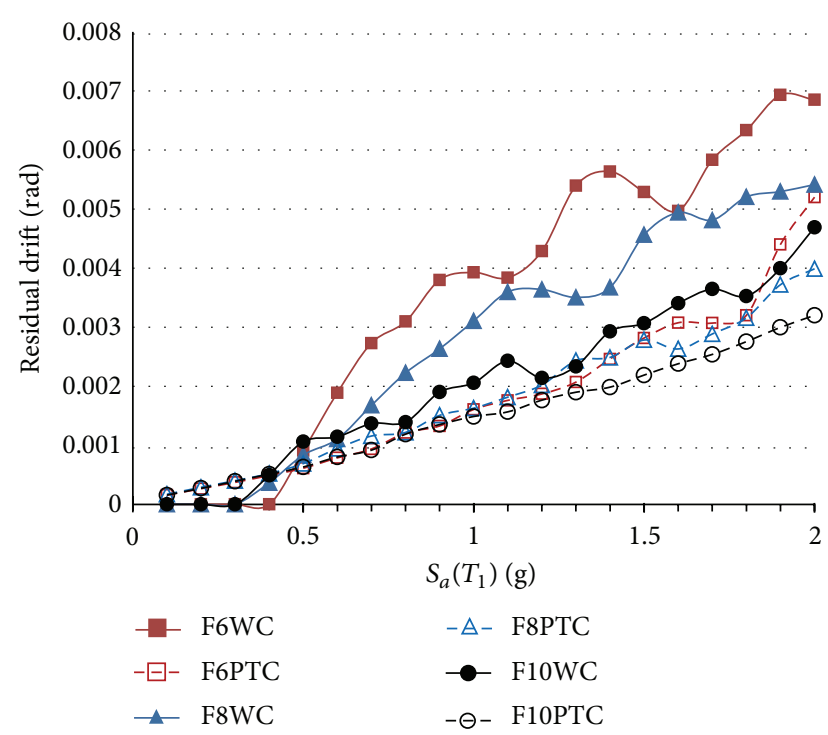

FIGURE 10: Median values of maximum residual interstory drift of the frames FWC and FPTC. there is a lack of dependence on the fundamental period of structural vibration in the values of RIDR $_{\max }$ at different intensity scaling levels, in such a way that for FPTC with different stories the residual demands are similar for the same spectral acceleration intensity.

The ratio of residual interstory drift demands for the FWC and FPTC structural systems defined as RRD is introduced to compare the structural performance of both types of systems. Figure 11 shows the mean values of RRD for all the frames under consideration at different intensity scaling levels starting from $0.5 \mathrm{~g}$; for smaller values, the structures exhibit elastic behaviour. Note that for a specific frame the ratio tends to be constant for all the intensity values under consideration; also, the ratio increases when the structural fundamental period is larger. This is summarized in Table 3, where the mean and standard deviation of RRD are presented for the frames obtained for all the scaling levels. Results indicate that the mean value increases and the standard deviation $(\sigma)$ decreases as the fundamental structural period increases, which implies a large difference in mean and in dispersion of the results corresponding to the frames under 


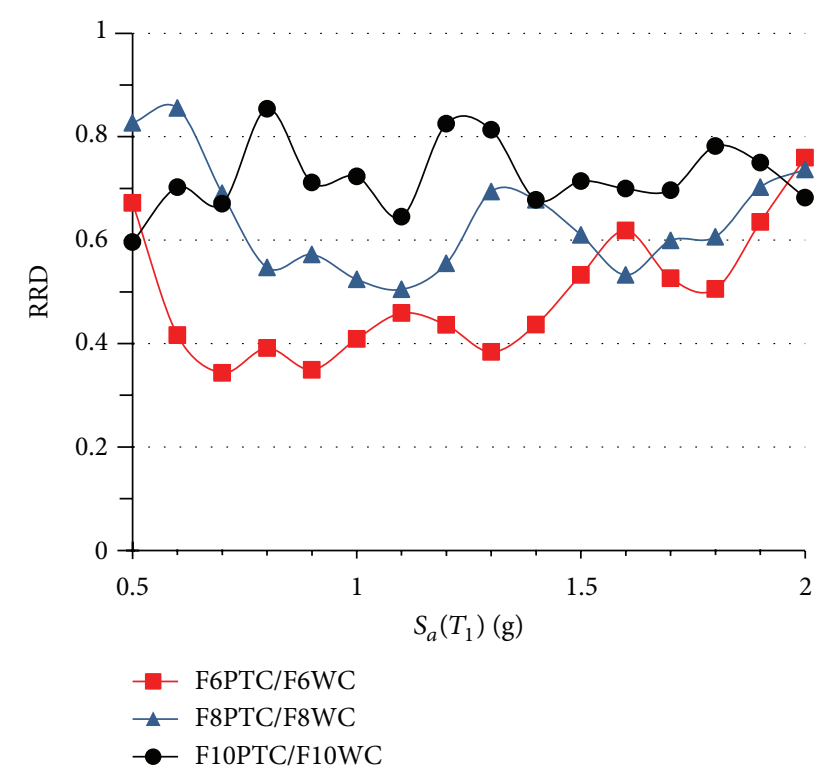

FIGURE 11: Ratios of mean values of RIDR $_{\max }$ for FPTC divided by $\mathrm{RIDR}_{\text {max }}$ for FWC.

TABLE 3: Mean and standard deviation of RRD values.

\begin{tabular}{lcc}
\hline Ratio of RIDR & Mean & Standard deviation \\
\hline F6PTC/F6WC & 0.49 & 0.123 \\
F8PTC/F8WC & 0.64 & 0.106 \\
F10PTC/F10WC & 0.72 & 0.069 \\
\hline
\end{tabular}

study. For the 6 stories frame the mean RRD is about 0.49 ; this implies that the average of the residual interstory drift for F6PTC is about 51\% smaller than the F6WC residual interstory drift. In the same way, the reductions are of $36 \%$ and $28 \%$ for the 8 -story and 10 -story frames, respectively. The results show the advantage of using posttensioned structural systems with energy dissipating connections.

\section{Conclusions}

The study compares the seismic performance of buildings in terms of maximum and residual interstory drifts' demands of posttensioned self-centering moment-resisting steel frames with traditional welded connection steel frames. Incremental nonlinear dynamic analysis was used to estimate the seismic assessment of six structural steel frames which were subjected to thirty long-duration ground-motion records scaled at different values of $S_{a}\left(T_{1}\right)$. For the analyses of the frames, nonlinear material behavior was considered. The numerical study indicates that in all the cases, the maximum interstory drifts of the FPTC are smaller than those of the FWC; in fact, reductions in the order of $47 \%$ were obtained when the FPTC was employed as structural system compared with the traditional system. Moreover, the residual interstory drifts for the FPTC systems are smaller than $0.5 \%$ which is the limit for feasible financially structures and to guarantee the comfort of the occupants of the buildings, and this conclusion is valid for different intensity levels. Furthermore, the maximum residual interstory drift was reduced at values as large as $51 \%$ when the frames have posttensioned connections. For this reason, the results suggest that $\mathrm{PT}$ connections in structural frame buildings can control significantly the seismic performance in terms of peak and residual drift demands for structures subjected to long-duration narrow-band earthquake ground motions, and this is valid for frames with different story levels and at different intensity of the ground motion. Note that most of the previous studies were developed using low-rise buildings which were subjected only to broad-band records.

Finally, it is important to say that the reduction of the maximum interstory drift implies less structural damage in the buildings and, on the other hand, the reduction of the maximum residual interstory drift is very important to reduce the economic consequences of repairing and interruption of the functionality of the buildings.

\section{Akcnowledgments}

The support given by the Universidad Nacional Autónoma de México under Project PAPIIT-IN109011-3 and PROMEP is appreciated. Financial support also was received from El Consejo Nacional de Ciencia y Tecnología to E. Bojórquez under Grant CB-2011-01-167419 and the Universidad Autónoma de Sinaloa under Grant PROFAPI 2012. Finally, the authors wish to express their gratitude to the anonymous reviewers for their suggestions to improve the quality of the paper.

\section{References}

[1] J. M. Ricles, R. Sause, M. Garlock, and C. Zhao, "Post-tensioned seismic-resistant connections for steel frames," Journal of Structural Engineering, vol. 127, no. 2, pp. 113-121, 2001.

[2] J. M. Ricles, R. Sause, S. W. Peng, and L. W. Lu, "Experimental evaluation of earthquake resistant posttensioned steel connections," Journal of Structural Engineering, vol. 128, no. 7, pp. 850859, 2002.

[3] C. Christopoulos, A. Filiatrault, and C. M. Uang, "Self-centering post-tensioned energy dissipating (PTED) steel frames for seismic regions," Tech. Rep. SSRP-2002/06, University of California, 2002.

[4] C. Christopoulos and A. Filiatrault, "Seismic response of posttensioned energy dissipating moment resisting steel frames," in Proceedings of the 12th European Conference on Earthquake Engineering, no. 61, London, UK, 2002.

[5] M. Garlock, J. Ricles, and R. Sause, "Experimental studies on full-scale post tensioned steel connections," Journal of Structural Engineering, vol. 131, no. 3, pp. 438-448, 2005.

[6] M. Garlock, R. Sause, and J. Ricles, "Behavior and design of post-tensioned steel frames system," Journal of Structural Engineering, vol. 133, no. 3, pp. 389-399, 2007.

[7] M. M. Garlock, J. M. Ricles, and R. Sause, "Influence of design parameters on seismic response of post-tensioned steel MRF systems," Engineering Structures, vol. 30, no. 4, pp. 1037-1047, 2008.

[8] P. Rojas, J. M. Ricles, and R. Sause, "Seismic performance of post-tensioned steel moment resisting frames with friction 
devices," Journal of Structural Engineering, vol. 131, no. 4, pp. 529-540, 2005.

[9] C.-C. Chou and J. H. Chen, "Column restraint in post-tensioned self-centering moment frames," Earthquake Engineering and Structural Dynamics, vol. 39, no. 7, pp. 751-774, 2010.

[10] C.-C. Chou and J. H. Chen, "Tests and analyses of a full-scale post-tensioned RCS frame subassembly," Journal of Constructional Steel Research, vol. 66, no. 11, pp. 1354-1365, 2010.

[11] C.-C. Chou and J.-H. Chen, "Seismic design and shake table test of a steel post-tensioned self-centering moment frame with a slab accommodating frame expansion," Earthquake Engineering and Structural Dynamics, vol. 40, pp. 1241-1261, 2011.

[12] C. C. Chou and J. H. Chen, "Analytical model validation and influence of column bases for seismic responses of steel posttensioned self-centering MRF systems," Engineering Structures, vol. 33, no. 9, pp. 2628-2643, 2011.

[13] E. Bojórquez and S. E. Ruiz, "Strength reduction factors for the valley of Mexico taking into account low cycle fatigue effects," in Proceedings of the 13th World Conference on Earthquake Engineering, no. 516, Vancouver, Canada, 2004.

[14] A. Teran-Gilmore and J. O. Jirsa, "Energy demands for seismic design against low-cycle fatigue," Earthquake Engineering and Structural Dynamics, vol. 36, no. 3, pp. 383-404, 2007.

[15] E. Bojórquez, A. Reyes-Salazar, A. Terán-Gilmore, and S. E. Ruiz, "Energy-based damage index for steel structures," Steel and Composite Structures, vol. 10, no. 4, pp. 343-360, 2010.

[16] E. Bojórquez, A. Terán-Gilmore, S. E. Ruiz, and A. ReyesSalazar, "Evaluation of structural reliability of steel frames: inter-story drifts versus plastic hysteretic energy," Earthquake Spectra, vol. 27, no. 3, pp. 661-682, 2011.

[17] G. A. Macrae and K. Kawashima, "Post-earthquake residual displacements of bilinear oscillators," Earthquake Engineering and Structural Dynamics, vol. 26, no. 7, pp. 701-716, 1997.

[18] C. Christopoulos, S. Pampanin, and M. J. N. Priestley, "Performance-based seismic response of frame structures including residual deformations. Part I: single-degree of freedom systems," Journal of Earthquake Engineering, vol. 7, no. 1, pp. 97-118, 2003.

[19] J. Ruiz-García and E. Miranda, "Residual displacement ratios for assessment of existing structures," Earthquake Engineering and Structural Dynamics, vol. 35, no. 3, pp. 315-336, 2006.

[20] S. Pampanin, C. Christopoulos, and M. J. N. Priestley, "Performance-based seismic response of frame structures including residual deformations. Part II: multi-degree of freedom systems," Journal of Earthquake Engineering, vol. 7, no. 1, pp. 119-147, 2003.

[21] J. McCormick, H. Aburano, M. Ikenaga, and M. Nakashima, "Permissible residual deformation levels for building structures considering both safety and human elements," in Proceedings of the 14th Conference on Earthquake Engineering, Beijing, China, October 2008.

[22] E. Bojórquez and Ruiz-García, "Residual drift demands in moment-resisting steel frames subjected to narrow-band earthquake ground motions," Earthquake Engineering and Structural Dynamics. In press.

[23] Mexico City Building Code, "Reglamento de Construcciones para el Distrito Federal (In Spanish)," 2004.

[24] J. Shen and A. Astaneh-Asl, "Hysteretic behavior of bolted-angle connections," Journal of Constructional Steel Research, vol. 51, no. 3, pp. 201-218, 1999.
[25] R. M. Richard and B. J. Abbott, "Versatile elastic plastic stressstrain formula," Journal of Engineering Mechanics, vol. 101, no. 4, pp. 511-515, 1975.

[26] A. Carr, RUAUMOKO Inelastic Dynamic Analysis Program, University of Canterbury, Department of Civil Engineering, 2011.

[27] M. D. Trifunac and A. G. Brady, "A study of the duration of strong earthquake ground motion," Bulletin of the Seismological Society of America, vol. 65, no. 3, pp. 581-626, 1975.

[28] E. Bojórquez, I. Iervolino, and G. Manfredi, "Evaluating a new proxy for spectral shape to be used as an intensity measure," in Proceedings of the Seismic Engineering International Conference Commemorating the 1908 Messina and Reggio Calabria Earthquake (MERCEA '08), 2008.

[29] E. Bojórquez and I. Iervolino, "Spectral shape proxies and nonlinear structural response," Soil Dynamics and Earthquake Engineering, vol. 31, no. 7, pp. 996-1008, 2011.

[30] E. Bojórquez, I. Iervolino, A. Reyes-Salazar, and S. E. Ruiz, "Comparing vector-valued intensity measures for fragility analysis of steel frames in the case of narrow-band ground motions," Engineering Structures, vol. 45, pp. 472-480, 2012.

[31] D. Vamvatsikos and C. A. Cornell, "Incremental dynamic analysis," Earthquake Engineering and Structural Dynamics, vol. 31, no. 3, pp. 491-514, 2002.

[32] M. A. Montiel and S. E. Ruiz, "Influence of structural capacity uncertainty on seismic reliability of buildings under narrowband motions," Earthquake Engineering and Structural Dynamics, vol. 36, no. 13, pp. 1915-1934, 2007. 

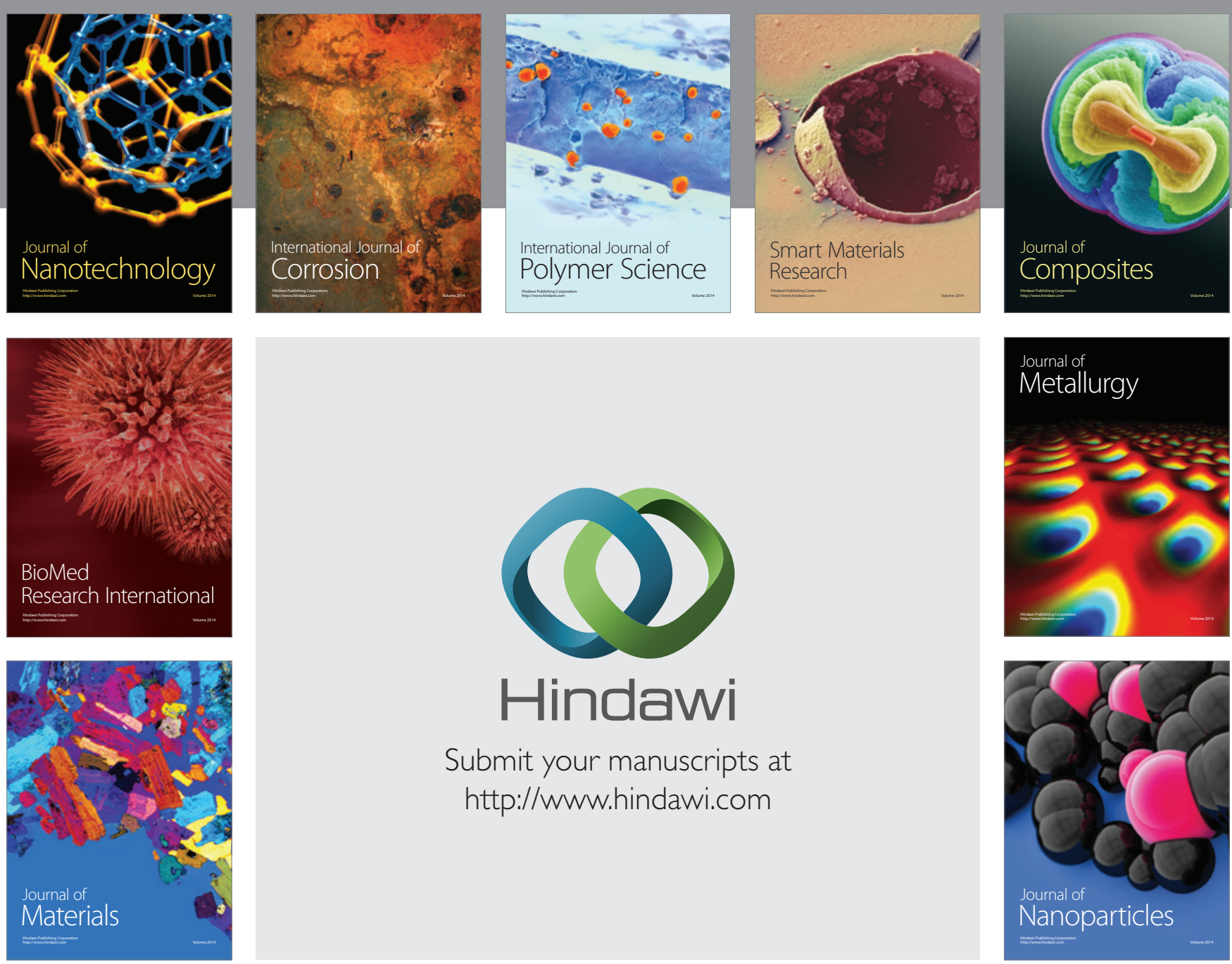

Submit your manuscripts at http://www.hindawi.com
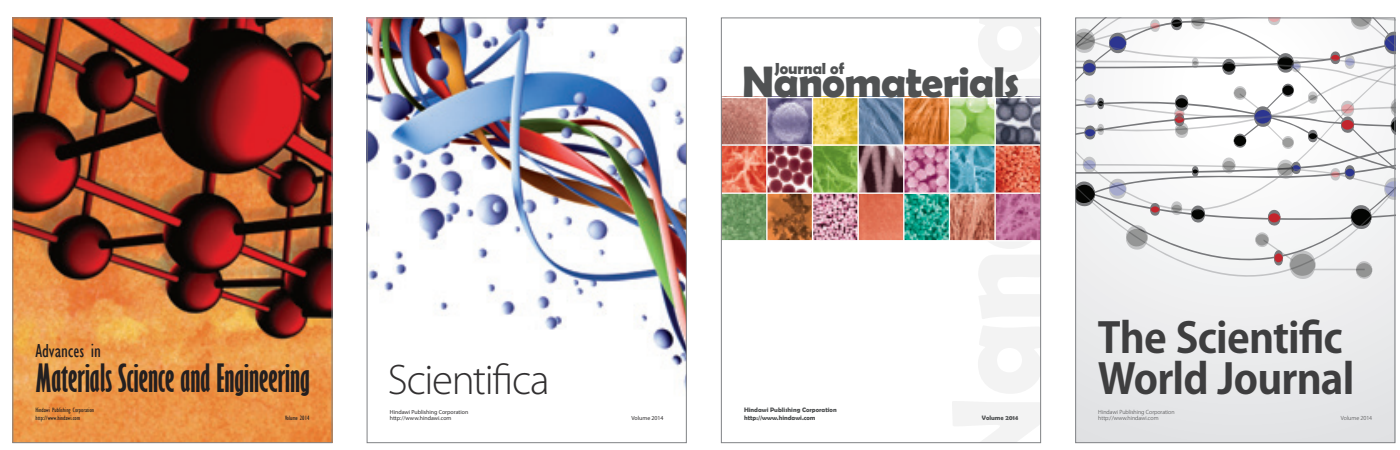

\section{The Scientific World Journal}
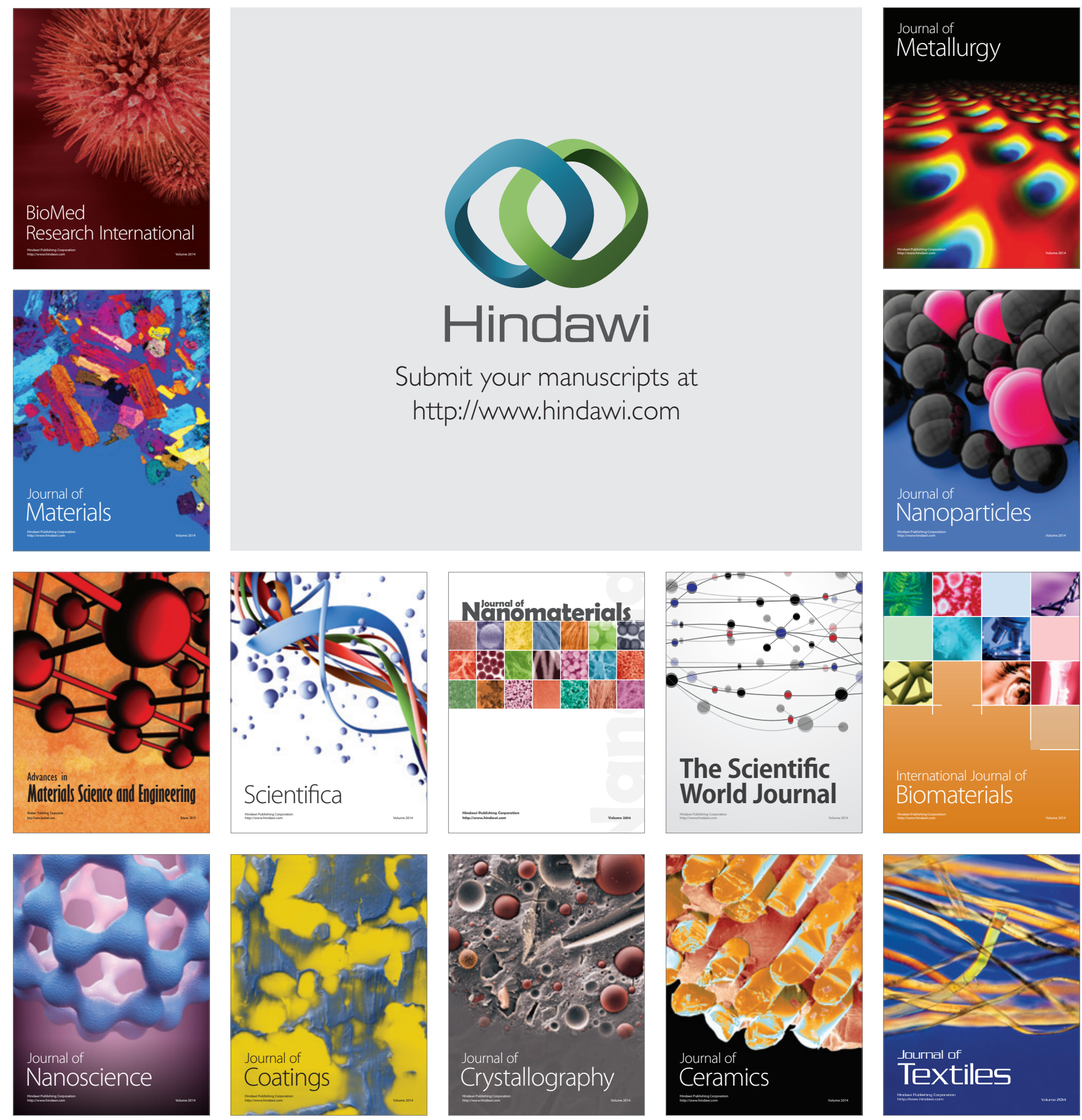